\title{
A New Lignan Derivative, Lasiocarpone, from The Stembark of Chisocheton iasiocarpus (Meliaceae)
}

\author{
A. T. HIDAYAT ${ }^{1,2}$, NURLELASARI ${ }^{1}$, F. F. ABDULLAH ${ }^{1}$, D. HARNETI ${ }^{1}$, \\ R. MAHARANI ${ }^{1,2}, K_{\text {. HAIKAL }}^{2}$, U. SUPRATMAN ${ }^{1,2 *}$ and M. N. AZMI ${ }^{3}$
'Department of Chemistry, Faculty of Mathematics and Natural Sciences, Universitas Padjadjaran, Jatinangor 45363, Sumedang, Indonesia.
${ }^{2}$ Central Laboratory, Universitas Padjadjaran, Jatinangor 45363, Sumedang, Indonesia.
${ }^{3}$ School of Chemical Sciences, Universiti Sains Malaysia, Minden 11800, Pulau Pinang, Malaysia.
${ }^{*}$ Corresponding author E-mail: unang.supratman@unpad.ac.id

http://dx.doi.org/10.13005/ojc/3404032

(Received: April 19, 2018; Accepted: June 01, 2018)

\section{ABSTRACT}

\begin{abstract}
A new lignan derivative, named lasiocarpone (1), was isolated from the stembark of Chisocheton lasiocarpus. The chemical structure of 1 was determined by extensive NMR and MS spectra analyses as well as by comparing with analogue compound from previous studies. Lasiocarpone showed moderate cytotoxic activity against MCF7 breast cancer cells with an IC ${ }_{50}$ value of $42.5 \mu \mathrm{M}$.
\end{abstract}

Keywords: Chisocheton lasiocarpus, Lignan, Lasiocarpone, Meliaceae, MCF7 cancer cell.

\section{INTRODUCTION}

The Chisocheton plant genera as a second largest plant of Meliaceae family, consisting of 50 plants and widely distributed in the tropics. Previous phytochemical studies of this genera have produced some compounds with interesting biological activity, such as anti-plasmodial ${ }^{1}$ limonoid $^{2}$, cytotoxic limonoid ${ }^{3}$, and anti-inflammatory limonoids ${ }^{4}$, NO production inhibitory activity limonoids ${ }^{5}$, cell growth inhibitory activity limonoids ${ }^{6}$, anti-inflammatory protolimonoids ${ }^{7}$, cytotoxic triterpenoid ${ }^{8}$ and cytotoxic tetranortriterpenoid ${ }^{9}$.
Our previous phytochemical studies on Chisocheton plants, we had found new limonoids, pentandrice and dysobinol from C. pentandrus ${ }^{10}$ and $C$. mocrophyllus ${ }^{11}$ as well as a triterpenoid-type lanostane from C. cumingianus ${ }^{12}$. In the further study, we focus the stembark of $C$. lasiocarpus that showed significant cytotoxic activity on MCF-7 breast cancer cells in vitro.

Chisocheton lasiocarpus is up to $20 \mathrm{~m}$ high plant and widely distributed in the tropical regions ${ }^{13}$. Traditionally, the stembark of $C$. lasiocarpus are used for treatment of fever and skin diseases ${ }^{13-15}$. There is

This is an Open Access article licensed under a Creative Commons Attribution-Non Commercial-Share Alike 4.0 International License (https://creativecommons.org/licenses/by-nc-sa/4.0/), which permits unrestricted Non Commercial use, distribution and reproduction in any medium, provided the original work is properly cited. 
no phytochemical study on C. lasiocarpus previously. In this paper, isolation, structure determination and cytotoxic activity of a new lignan derivative are described.

\section{MATERIAL AND METHOD}

\section{Instruments}

Optical rotation values were measured with a Perkin-Elmer 341 polarimeter. UV spectrum was measured with Shimadzu-1800 spectrophotometer. IR spectrum was measured on Perkin-Elmer 1760X spectrophotometer. Mass spectra was measured with a Qtof HR-MS XEVotm mass spectrometer instruments. NMR data were recorded on a Bruker Topspin spectrometer and used TMS as an internal standard. Column chromatography on $\mathrm{SiO}_{2}$ (Merck \& Co.). TLC analysis on $\mathrm{SiO}_{2} \mathrm{GF}_{254}$, stain was observed on UV light and heated on the hotplate after spraying with $10 \% \mathrm{H}_{2} \mathrm{SO}_{4}$ in ethanol.

\section{Plant Material}

C. lasiocarpus stembarks were obtained from Bogor Botanical Garden, Indonesia in July 2015. Plant identifications were made from Bogoriense Herbarium, Indonesia. Specimens (No. Bo-1295453) are saved in the Bogoriense Herbarium.

\section{Cytotoxic Assay}

Determination of cytotoxic activity is performed according to the procedure described in the previous paper ${ }^{10}$. Harvest suspension of breast cancer cells (MCF-7) by centrifugation. Determine the amount and viability cells (with trypan blue exclusion), and resuspend cells with final $4 \times 10^{5}$ cells / $\mathrm{mL}$ supplemented with $10 \%$ phosphoric buffer solution (FBS) and 1\% Penicillin-Streptomycin. Dispense $50 \mu \mathrm{L}$ of cell suspension (20,000 cells) into all wells on microplate, then incubated for 24 hours. On different microplate samples were prepared. Samples or standards to be measured, diluted in an EMEM medium containing 10\% FBS and $1 \%$ Penicillin-Streptomycin, then dilutions. The diluted $50 \mu \mathrm{L}$ sample was transferred into well on the microplate containing the incubated cell. Then re-incubated for 48 hours. After that, a salt 3-(4,5-dimethylthiazol-2-yl)-5-(3-carboxy -methoxyphenyl)-2-(4-sulfophenyl)-2H-tetrazolium) (MTS) reagent was introduced to each microplate of $20 \mu \mathrm{L}$ and incubated for 2-4 hours until the orange formazan was seen. Furthermore, the colored formazan that has been produced measured its absorbance at a wavelength of $570 \mathrm{~nm}$ using a multimode reader. The $\mathrm{IC}_{50}$ value was obtained from percentage live cells compared to control (\%), versus the tested concentration of compounds $(\mu \mathrm{M})$.

\section{RESULTS}

\section{Extraction and Purification}

Dried ground stembarks of $C$. lasiocarpus $(2.1 \mathrm{~kg})$ were soaked with methanol for three days and filtered. Evaporate of the methanol on vacuum produced a concentrated methanol extract (209.4 g) and subsequently partitioned to $n$-hexane, EtOAc and $n$-BuOH. A portion of EtOAc $(28.3 \mathrm{~g})$ was vacuum liquid chromatographed on $\mathrm{SiO}_{2}$ with $n$-hexane-EtOAc-MeOH as a gradient solvent to yield seven fractions (I-VII). Fraction IV $(3.20 \mathrm{~g})$ was column chromatographed on $\mathrm{SiO}_{2}$ with $n$-hexane-EtOAc (10:0-1:1) as a developing solvent to give seven subfractions (IVa-IVg). Subfraction IVf $(420 \mathrm{mg}$ ) was further separated by column chromatography on $\mathrm{SiO}_{2}$ with choroform: methanol (9:1) as a solvent to give five subfractions (IVf.1-5). Subfraction IVf.3 (62.5 mg) was further purified by preparative TLC on $\mathrm{SiO}_{2} \mathrm{GF}_{254}$ with $n$-hexane: ethyl acetate (8:2) as a solvent to give $\mathbf{1}(5 \mathrm{mg})$ as a minor compound.

Lasiocarpone (1). Yellowish gum; $[\alpha]_{20}^{\mathrm{D}}+$ 25.1 (c 0.1, $\mathrm{CH}_{3} \mathrm{OH}$ ); UV $\lambda_{\max } 280$ ( $\left.\varepsilon 2.80\right)$; IR (KBr) $v_{\text {max }}\left(\mathrm{cm}^{-1}\right): 3394,3060,1731,1720,1560,1464$, 1024; ${ }^{1} \mathrm{H}-(500 \mathrm{MHz})$ and ${ }^{13} \mathrm{C}$ NMR $(125 \mathrm{MHz})$ in DMSO- $d_{6}$, Table 1. HR-TOFMS m/z 355.1015 [M+H] + (Calcd for $\mathrm{C}_{20} \mathrm{H}_{18} \mathrm{O}_{6}, \mathrm{~m} / z$ 354.1025).

\section{DISCUSSION}

An aqueous methanol extract was concentrated and partitioned to $n$-hexane, ethyl acetate, and $n$-butanol. The ethyl acetate fraction was column chromatographed on $\mathrm{SiO}_{2}$ and separated on preparative TLC on $\mathrm{SiO}_{2} \mathrm{GF}_{254}$ produce a new lignan derivative, lasiocarpone (1).

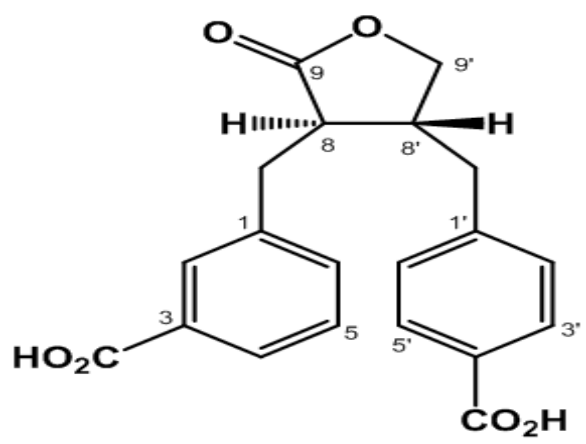

1 
Lasiocarpone (1), $[\alpha]^{25}+25.1^{\circ}$ (c 0.1 , $\mathrm{CH}_{3} \mathrm{OH}$ ), was isolated as a yellowish gum with molecular formula, $\mathrm{C}_{20} \mathrm{H}_{18} \mathrm{O}_{6}$ by high resolution time of flight mass spectra (HR-TOFMS), requiring twelve double bond equivalents. UV absorption of 1 in $\mathrm{MeOH}$ exhibited at $280 \mathrm{~nm}$, indicating the presence on benzene ring. IR spectrum showed peaks at $3394,1731,1720,1560$ and $1024 \mathrm{~cm}^{-1}$, due to the presence of hydroxyl, carboxyl ester lactone, benzene and ether groups. ${ }^{1} \mathrm{H}-\mathrm{NMR}$ spectrum of 1 revealed $p$-disubstituted benzene ring at $\delta_{H} 7.52$ $(2 \mathrm{H}, \mathrm{d}, \mathrm{J}=6.8 \mathrm{~Hz}, \mathrm{H}-2, \mathrm{H}-6)$ and $7.43(2 \mathrm{H}, \mathrm{d}, \mathrm{J}=6.4$ $\mathrm{Hz}, \mathrm{H}-3, \mathrm{H}-5)$. In ${ }^{1} \mathrm{H}-\mathrm{NMR}$ spectrum showed also $m$-disubstituted benzene ring at $\delta \mathrm{H} 7.26[(1 \mathrm{H}, \mathrm{d}$, $J=7.1 \mathrm{~Hz}, \mathrm{H}-4), 7.70(1 \mathrm{H}, \mathrm{dd}, J=7.1,8.2 \mathrm{~Hz}, \mathrm{H}-5)$, $7.77(1 \mathrm{H}, \mathrm{d}, \mathrm{J}=8.2 \mathrm{~Hz}, \mathrm{H}-6)$ and $7.18(1 \mathrm{H}, \mathrm{s}, \mathrm{H}-2)]$. In addition, deshielded methylene protons at $\delta_{\mathrm{H}}$ [4.45 $(1 \mathrm{H}, \mathrm{dd}, J=7.1,8.5 \mathrm{~Hz}), 4.54(1 \mathrm{H}, \mathrm{dd}, J=8.5$, $9.4 \mathrm{~Hz})]$, methine signals at $\delta_{\mathrm{H}}[4.67(1 \mathrm{H}, \mathrm{dd}, \mathrm{J}=4.7$, $7.1 \mathrm{~Hz}), 4.19(1 \mathrm{H}, \mathrm{m})]$ and four methylene signals at $\delta_{\mathrm{H}} 2.87(1 \mathrm{H}, \mathrm{dd}, \mathrm{J}=5.5,13.8 \mathrm{~Hz}), 3.24(1 \mathrm{H}$, dd, $J=7.1,13.8 \mathrm{~Hz}), 3.05(1 \mathrm{H}, \mathrm{dd}, J=10.4,13.5 \mathrm{~Hz})$ and $3.20(1 \mathrm{H}, \mathrm{dd}, \mathrm{J}=4.7,13.5 \mathrm{~Hz})$ also were observed and supporting of a dibenzyl butyrolactone-type lignin ${ }^{16}$. The ${ }^{13} \mathrm{C}-\mathrm{NMR}$ spectrum together with DEPT spectrum of $\mathbf{1}$ displayed twenty carbon signals, including a lactone $\left(\delta_{C} 171.9\right)$, two carboxyl carbons $\left(\delta_{c} 167.2,166.7\right)$, four $s p^{2}$ quartenary carbons, eight $\mathrm{sp}^{2}$ methines, an oxygenated $\mathrm{sp}^{3}$ methylene $\left(\delta_{\mathrm{C}} 65.9\right)$, two $\mathrm{sp}^{3}$ methylenes and two $\mathrm{sp}^{3}$ methines, featuring a dibenzyl butyrolactonetype lignan ${ }^{16,17}$. A NMR data of 1 are similar those of (2R,3R)-2-(4-hydroxy-3-methoxybenzyl)3-(3,4,5-trimethoxy)benzylbuyrolactone ${ }^{17}$, except the disappear of methoxyl and hydroxyl groups and the appearance of carboxyl group. In order to clarify the position of functional groups, 2D NMR experiments were conducted (Fig. 1). Correlations in $\mathrm{H}^{\prime}$ - $-\mathrm{H}^{\prime}$, $\mathrm{H}^{\prime}-\mathrm{H} 66^{\prime}, \mathrm{H} 4-\mathrm{H} 5-\mathrm{H} 6, \mathrm{H} 7-\mathrm{H} 8$ and $\mathrm{H} 7{ }^{\prime}-\mathrm{H} 8^{\prime}-$ $\mathrm{H}^{\prime}$, supporting the presence of a 1, 4-disubtituted and a 1,3-disubtituted benzene ring from a dibenzyl butyrolactone-type lignan.

All of aromatic protons were correlated to carboxyl and used for assigment of the carboxyl groups were attached in meta and para orientation, respectively. Furthermore, a correlation between an oxygenated methylene at $\delta_{H} 4.45$ to $\mathrm{C}-9\left(\delta_{\mathrm{C}} 171.9\right)$ and $\mathrm{C}-8^{\prime}\left(\delta_{\mathrm{C}}\right.$ 50.3) and a methine proton at $\delta_{\mathrm{H}} 4.67$ to $\mathrm{C}-9\left(\delta_{C}\right.$ 171.9) were used to assign a lactone ring at C-8, C-9, C-9' and C-8', which characteristic for butyrolactone-type of lignan. Correlation from methylene protons at $\delta_{\mathrm{H}} 3.07$ and 2.87 to aromatic carbons at $\delta_{\mathrm{C}} 137.8(\mathrm{C}-1), 138.2\left(\mathrm{C}-1^{\prime}\right)$ and to methine carbons at $\delta_{\mathrm{C}} 54.8(\mathrm{C}-8)$ and $50.3\left(\mathrm{C}-8^{\prime}\right)$, supporting the dibenzyl butyrolactone-type of lignan. It was clearly confirmed that compound $\mathbf{1}$ contains a 3-carboxybenzyl at C-9 and 4'-carboxybenzyl unit C- $9^{\prime}$ on a butyrolactone skeleton and the relative configuration of the dibenzyl units is trans. A relative stereochemistry of C-8 and C-8' was supported also by NOESY spectra. There are no crosspeak between $\mathrm{H}-8$ and $\mathrm{H}-8$ ' In the NOE spectra, consequently both protons are trans-orientation.

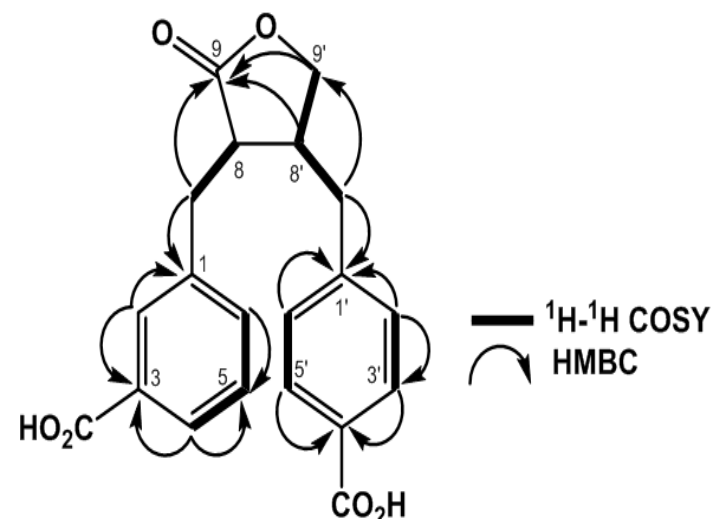

Fig. 1. Selected correlations for 1

This results was supported also by comparing to those of trans-dibenzylbutyrolactone ${ }^{18}$ and the specific optical rotation of $1\left([\alpha]^{20}{ }_{\mathrm{D}}\right.$ $24.1^{\circ}, \mathrm{c} 0.1, \mathrm{CH}_{3} \mathrm{OH}$ ) is same negative sign to that of the previously reported, $(2 R, 3 R)-2$ -(4-hydroxy-3-methoxybenzyl)-3-(3,4,5-trimethoxy) benzylbuyrolactone $\left([\alpha]_{D}^{18}-25.1^{\circ} \text { (c 0.55, EtOH) }\right]^{17}$. Therefore, compound 1 was elucidated to be a new dibenzyl butyrolactone-type lignan, $(2 R, 3 R)$ 5-carboxybenzyl-4'-carboxybenzylbutyrolactone and was named lasiocarpone.

Lasiocarpone (1) was checked its cytotoxic activity on MCF-7 breast cancer cells according to a method described ${ }^{10,19}$ and cisplatin $\left(\mathrm{IC}_{50} 27.0\right.$ $\mu \mathrm{M})$ was used as a positive control ${ }^{20}$. Lasiocarpone 
Table 1: NMR data for Lasiocarpone

\begin{tabular}{crc}
\hline Position of $\mathrm{C}$ & $\delta_{\mathrm{C}}$ (mult.) & $\delta_{\mathrm{H}}(\Sigma \mathrm{H} .$, Integral., J=Hz) \\
\hline 1 & $137.8(\mathrm{~s})$ & - \\
2 & $129.6(\mathrm{~d})$ & $7.18(1 \mathrm{H}, \mathrm{s})$ \\
3 & $134.0(\mathrm{~s})$ & - \\
4 & $126.9(\mathrm{~d})$ & $7.26(1 \mathrm{H}, d, 7.1)$ \\
5 & $127.6(\mathrm{~d})$ & $7.70(1 \mathrm{H}, d d, 7.1,8.2)$ \\
6 & $128.5(\mathrm{~d})$ & $7.77(1 \mathrm{H}, d, 8.2)$ \\
7 & $36.4(\mathrm{t})$ & $3.05(1 \mathrm{H}, d d, 10.4,13.5)$ \\
& & $3.20(1 \mathrm{H}, d d, 4.7,13.5)$ \\
8 & $54.5(\mathrm{~d})$ & $4.67(1 \mathrm{H}, d d, 4.7,7.1)$ \\
9 & $171.8(\mathrm{~s})$ & - \\
$1^{\prime}$ & $138.0(\mathrm{~s})$ & - \\
$2^{\prime}$ & $131.5(\mathrm{~d})$ & $7.52(1 \mathrm{H}, d, 6.8)$ \\
$3^{\prime}$ & $128.6(\mathrm{~d})$ & $7.43(1 \mathrm{H}, d, 6.4)$ \\
$4^{\prime}$ & $134.8(\mathrm{~s})$ & - \\
$5^{\prime}$ & $128.6(\mathrm{~d})$ & $7.40(1 \mathrm{H}, d, 6.4)$ \\
$6^{\prime}$ & $131.5(\mathrm{~d})$ & $7.60(1 \mathrm{H}, d, 6.8)$ \\
$7^{\prime}$ & $36.7(\mathrm{t})$ & $2.87(1 \mathrm{H}, d d, 5.5,13.8)$ \\
& & $3.24(1 \mathrm{H}, d d, 7.1,13.8)$ \\
$8^{\prime}$ & $50.3(\mathrm{~d})$ & $4.19(1 \mathrm{H}, \mathrm{m})$ \\
$9^{\prime}$ & $65.9(\mathrm{t})$ & $4.45(1 \mathrm{H}, d d, 7.1,8.5)$ \\
& & $4.54(1 \mathrm{H}, d d, 8.5,9.4)$ \\
$4^{\prime}-\mathrm{CO}_{2} \mathrm{H}$ & $166.7(\mathrm{~s})$ & - \\
$5-\mathrm{CO}_{2} \mathrm{H}$ & $167.2(\mathrm{~s})$ & - \\
\hline
\end{tabular}

displayed an $\mathrm{IC}_{50}$ value of $42.5 \mu \mathrm{M}$ against MCF-7 breast cancer cell, indicating showed moderate cytotoxic activity.

\section{CONCLUSION}

A new dibenzyl butyrolactone-type lignan derivative, lasiocarpone (1), was isolated from the stembark of Chisocheton lasiocarpus as a minor compound. This investigation confirm that Chisocheton genus is capable to produce a lignan derivative.

\section{ACKNOWLEDGMENT}

We express sincerely thank to Universitas Padjadjaran for financial support (Academic Leadership Grant 2016-2018 by US). We are thankful to Dr. Yuni Elsa at Central Laboratory, Universitas Padjadjaran, Bandung, Indonesia for MCF7 assay.

\section{REFERENCES}

1. Yang, M.H.; Wang, J.S.; Luo, J.G.; Wang, X.B., Kong, L.Y. J. Nat. Prod., 2009, 72, 2014-2018.

2. Mohamad, K.; Hirasawa, Y.; Litaudon, M.; Awang, K.; Hadi, A.HA.; Takeya, K.; Ekasari, W.; Widyawaruyanti, A.; Zaini, N.C.; Morita, H. Bioorganic and Medicinal Chemistry., 2009, 17, 727-730.

3. Wong, C.P.; Shimada, M.; Nugroho, A.E.; Hirasawa, Y.; Kaneda, T.; Hadi, A.H.A.; Osamu, S.; Morita, H. J. Nat. Med., 2012, 66, 566-570.

4. Chong, S,L.; Awang, K.; Martin, M,T.; Mokhtar, M.R.; Chan, G.; Litaudon, M.; Gueritte, F.; Mohamad, K. Tetrahedron Letters., 2012, 53, 5355-5359.

5. Najmuldeen, I,A.; Hadi, A.HA.; Awang, K.; Mohamad, K.; Ketuly, K.A.; Mukhtar, M.R.; Chong, S.L.; Chan, G.; Nafiah, M.A.; Weng, N.S.; Shirota, O.; Hosoya, T.; Nugroho, A.E.; Morita, H. J. Nat. Prod., 2011, 74, 1313-1317.

6. Wong, C.P.; Shimada, M.; Nagakura, Y.; Nugroho, A.E.; Hirasawa, Y.; Kaneda, T.; Awang, K.; Hadi, A.H.A.; Mohamad, K.; Shiro, M.; Morita, H. Chem. Pharm. Bull., 2011, 59(3), 407-411.

7. Yang, M.H.; Wang, J.S.; Luo, J.G.; Wang,
X.B.; Kong, L.Y. Bioorganic and Medicinal Chemistry., 2011, 19, 1409-1417.

8. Yang, M.H.; Wang, J.S.; Luo, J.G.; Wang, X.B.; Kong, L.Y. Can. J. Chem., 2012, 90, 199-204.

9. Inada, A.; Sukemawa, M.; Murata, H.; Nakanishi, T.; Tokuda, H.; Nishino, H.; Iwashima, A.; Darnaedi, D.; Murata, J. Chem. Pharm. Bull., 1993, 41, 617-619.

10. Supriatno.; Nurlelasari., Herlina, T.; Harneti, D.; Maharani, R.; Hidayat, A,T.; Mayanti, T.; Supratman, U.; Azmi, M.N.; Shiono, Y. Natural Products Research., 2018, 32, 1-7.

11. Nurlelasari.; Katja, D.G.; Harneti, D.; Wardayo, M.M.; Supratman, U.; Awang, K. Chemistry of Natural Compounds., 2017, 53, 83-87.

12. Katja, D,G.; Farabi, K.; Nurlelasari.; Harneti, D.; Mayanti, T.; Supratman, U.; Awang, K.; Hayashi, H. Journal of Asian Natural Products Research., 2016, 6, 1-5.

13. Bordoloi, M.; Saikia, B.; Mathur, R. K.; Goswami, B. N. Phytochemistry., 1993, 34, 583-584.

14. Connolly, J.D.; Labbe, C.; Rycroft, D.S.; Taylor, D.A.H. J. Chem. Soc. Perkin Trans. I., 1979, 12, 2959-2964. 
15. Heyne, K., "The Useful Indonesian Plants", Research and Development Agency, Ministry of Forestry, Jakarta, Indonesia. 1982, 989-1012.

16. Kader, A.M.S.; Wisse, J.; Evans, R.; Werff, H.V.D.; Kingston, D.G.I. J. Nat. Prod., 1997, 60, 1294-1297.

17. Nishibe, S.; Okabe, K.; Hisada. Chem. Pharm. Bull., 1981, 29(7), 2078-2082.

18. Chenevert, R and Rose, Y.S. Tetrahedron:
Asymmetry., 1998, 9, 2827-2831.

19. Skehan, P.; Storeng, R.; Scudiero, D.; Monks, A.; McMahon, J.; Vistica, D.; Warren, J.T.; Bokesch, H.; Kenney, S.; Boyd, R.M. J. Natl. Cancer Inst., 1990, 82, 1107-1112.

20. Hadisaputri, Y.E.; Pharm, D.; Miyazaki, T.; Suzuki, S.; Yokobori, T.; Kobayashi, T.; Tanaka, N.; Inose, T.; Sohda, M and Kuwano, H. Ann. Surg. Oncol., 2012, 19, S589-S596. 